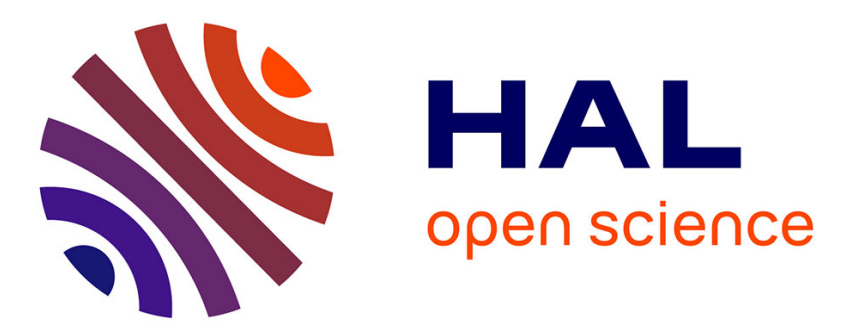

\title{
Influence of the adhesive layer on the mechanical properties of thin veneer-based composite materials
}

Beate Buchelt, André Wagenführ

\section{To cite this version:}

Beate Buchelt, André Wagenführ. Influence of the adhesive layer on the mechanical properties of thin veneer-based composite materials. European Journal of Wood and Wood Products, 2009, 68 (4), pp.475-477. 10.1007/s00107-009-0389-y . hal-00568262

\section{HAL Id: hal-00568262 \\ https://hal.science/hal-00568262}

Submitted on 23 Feb 2011

HAL is a multi-disciplinary open access archive for the deposit and dissemination of scientific research documents, whether they are published or not. The documents may come from teaching and research institutions in France or abroad, or from public or private research centers.
L'archive ouverte pluridisciplinaire HAL, est destinée au dépôt et à la diffusion de documents scientifiques de niveau recherche, publiés ou non, émanant des établissements d'enseignement et de recherche français ou étrangers, des laboratoires publics ou privés. 


\section{空 Springer}

Draft Manuscript for Review

\section{Influence of the adhesive layer on the mechanical properties of thin veneer-based composite materials}

\begin{tabular}{|r|l|}
\hline Journal: & Holz als Roh- und Werkstoff \\
\hline Manuscript ID: & HRW-09-0029.R1 \\
\hline Manuscript Type: & KURZORIGINALIA / BRIEF ORIGINALS \\
\hline $\begin{array}{r}\text { Date Submitted by the } \\
\text { Author: }\end{array}$ & 21-Apr-2009 \\
\hline Complete List of Authors: & $\begin{array}{l}\text { Buchelt, Beate; TU Dresden, Inst. für Holz- und Papiertechnik } \\
\text { Wagenführ, André; TU Dresden, Inst. f. Holz- und Papiertechnik }\end{array}$ \\
\hline Keywords: & $\begin{array}{l}\text { veneer, mechanical properties, veneer-based materials, beech, } \\
\text { adhesive bonding, composite }\end{array}$ \\
\hline \multicolumn{2}{|l}{} \\
\hline
\end{tabular}

\section{S ScholarONE" \\ Manuscript Central}




\title{
Influence of the adhesive layer on the mechanical properties of thin veneer-based composite materials
}

\author{
Technische Universität Dresden \\ Institute of Wood and Paper Technology \\ 01062 Dresden \\ E-mail: $\quad$ beate.buchelt@tu-dresden.de
}

\begin{abstract}
Subject
For the production of spliced veneers the veneers are coated with thin cellulose fleece or special paper layers, and thereby thin composites are generated. This article describes the mechanical properties of such a composite material consisting of $0.35 \mathrm{~mm}$ beech (Fagus sylvatica L.) veneer and a $0.12 \mathrm{~mm}$ cellulose fleece bonded with a PVAc adhesive.

The investigations showed that the mechanical properties of materials based on thin veneers are significantly influenced by the applied adhesive. The modulus of elasticity perpendicular to the wood fibre is considerably increased which is disadvantageous to the flexibility of the material but does have advantages for components that need to withstand high static loads.
\end{abstract}




\section{Introduction}

Not only for the production of spliced veneers but also for improved further processing veneers are coated with thin cellulose fleece or special paper layers. During this process a composite material with a thickness of $0.3 \ldots 0.6 \mathrm{~mm}$ is produced. Considering the overall thickness of the material an adhesive with approximately 50 microns represents a significant percentage of the total. Several investigations regarding the mechanical characterisation of the woodadhesive interphase give prove of a change in the modulus of elasticity (MOE) and the strength of the cell walls in the interphase region (Gindl et al 2003; Konnerth and Gindl 2006). These previous studies determined the MOE from cell walls which were penetrated with different adhesives.

In this study the changing mechanical properties of thin veneer-based composite materials due to the adhesive layer is investigated. In order to obtain representative results the tests were carried out on many different thin composite materials. These composites comprise veneer and cellulose fleece. The tests were done with different wood species, veneer thickness, type of fleece and adhesive. The used composites would normally feature a parallel arrangement of the veneer fibre and the fabrication direction of the fleece.

In the following article the mechanical properties of a composite material consisting of $0.35 \mathrm{~mm}$ beech (Fagus sylvatica L.) veneer and a $0.12 \mathrm{~mm}$ cellulose fleece bonded with a PVAc adhesive are described as an example.

\section{Materials and Methods}

For this study beech veneers made from a suitable board on a lengthwise wood slicing machine with consequent sanding to approximately $0.35 \mathrm{~mm}$ were used. The veneers were then bonded with the cellulose fleece using PVAc adhesive resulting in a composite material. The fibre direction of the veneer was arranged parallel to the original fabrication direction.

In order to evaluate the mechanical properties of the tested materials a series of tensile tests parallel and perpendicular to the wood fibre were done on the composites as well as on the individual materials. 
The veneers were tested parallel and perpendicular to the wood fibre whereas the latter corresponds to the radial direction in the wood.

The tensile test for the veneer parallel to the fibre was done with a standard test machine and with rectangular samples of the size $14 \mathrm{~mm}$ (width) x $120 \mathrm{~mm}$ (length) $\mathrm{x}$ thickness of the material (see Table 1 and 2). The strain measurement was done with a video extensometer by capturing continuous images of the specimen during the test, using a frame grabber camera attached to a PC. Thereby the alternation of length was determined between two measuring marks sticking on the specimen with a distance of approximately $1 \mathrm{~cm}$ of the clamping. The tensile tests perpendicular to the fibre of the veneers could not be carried out satisfactorily with these test parameters. The test samples deformed due to their low stiffness. As both parameters - required force and deformation - are accounted for in the measured value, the measurement would be flawed. For that reason the tensile tests perpendicular to the fibre were done on a micro testing device which allowed smaller test sample dimensions (width x length $6 \mathrm{~mm}$ x 60 $\mathrm{mm})$. The alternation of the length was then measured via the used stepping motor which also served as the drive. The deformation of the device was considered with a stiffness adjustment determined for this device with a steel sample. All measured values were corrected by this adjustment. The composite materials and the cellulose fleece were tested on a standard test machine. The dimensions of the test samples were $14 \mathrm{~mm}$ (width) x $120 \mathrm{~mm}$ (length) $\mathrm{x}$ fleece thickness or material thickness, respectively. For each material option at least 10 samples were tested except the cellulose fleece, where the number of samples was reduced to three.

The test samples were conditioned to $22^{\circ} \mathrm{C}$ and $60 \%$ relative humidity and remained constant during the test procedure. All samples were tested under the same conditions.

The test results were evaluated statistically. In order to analyse a significant difference between the mechanical properties an ,analysis of variance test“ (i.e., ANOVA-test) with a „two-random sample F-test“ was carried out. The level of significance was defined to be $5 \%$. 


\section{Results and discussion}

Table 1 shows the derived values from the tensile tests parallel to the wood fibre.

\section{Tab. 1}

The MOE for the beech veneer is significantly higher than that of the composite material. This result is as expected and mainly caused by the considerably lower MOE of the fleece which decreases the overall modulus. The parameters tensile strength and strain to rupture on the other hand do not indicate significant differences between the individual materials and the composite. It can therefore be concluded that the coating does not affect the parameters tensile strength and strain to rupture in the parallel direction of the wood fibre.

Table 2 shows the derived values from the tensile tests perpendicular to the wood fibre.

\section{Tab. 2}

The MOE of the composite material does have a considerably higher value than that of the veneer. The tensile strengths on the other hand do not vary significantly. Although the fleece does have a higher tensile strength than the veneer it does not increase the strength of the composite material since that fails before the tensile strength of the fleece is reached. The strain to rupture of the composite is consequently significantly lower than that of the veneer.

All in all the composite material is therefore stiffer while maintaining its tensile strength. This result is rather surprising since neither the cellulose fleece nor the veneer do have such a high MOE like the composite. It indicates that the cause must be sought in the bonding adhesive. Figure 1 shows a cross section of the tested composite. It can clearly be seen that the adhesive completely fills the cut cells and vessels of the wood.

\section{Fig. 1}

That is the reason for the increased MOE of the composite material. Due to the solid bonding of the cell walls of the vessels the potential for elongation is considerably reduced. In this context it seems that the thickness of the adhesive layer does not have a significant impact but more the fact that the adhesive is in the cell lumen. This also explains why the modulus of elasticity is not increased parallel to the wood fibre by applying adhesive. Due to the alignment of the 


\section{Acknowledgements}

This publication is based on a research project which was funded by the Federal Ministry of Education and Research of Germany (Grant Reference No. 01 RI 05115). The authors of this publication are solely responsible for its contents. We would like to express our thanks to Dipl.-Forstingenieur E. Bäucker who had kindly taken the REM-image (Fig. 1) at the Institute of Forest Utilization and Forest Technology.

\section{References}

Gindl W, Schöberl T, Jeronimides G (2003) The interphase in phenol-formaldehyde and polymeric methylene di-phenyl-di-isocyanate glue lines in wood. Int. J. Adhes. Adhes. 24: 279-286

Konnerth J, Gindl W (2006) Mechanical characterisation of wood-adhesive interphase cell walls by nanoindentation. Holzforsch. 60 (4): 429-433 


\section{Legend of figures}

Fig. 1 Composite made of beech veneer and cellulose fleece

Abb. 1 Verbundwerkstoff aus Rotbuchenfurnier und Cellulosevlies 


\section{Tables}

Table 1 Results of tensile tests parallel to the wood fibre

Tabelle 1 Ergebnisse der Zugprüfungen parallel zur Faserrichtung

\begin{tabular}{|l|r|r|r|r|}
\hline \multicolumn{1}{|c|}{ material } & thickness & $\begin{array}{c}\text { MOE, } \\
\text { mean value } \\
\text { (std. dev. })\end{array}$ & $\begin{array}{c}\text { tensile strength, } \\
\text { mean value } \\
\text { (std. dev. })\end{array}$ & $\begin{array}{c}\text { strain to rupture, } \\
\text { mean value } \\
\text { (std. dev.) }\end{array}$ \\
\hline veneer & $0.36 \mathrm{~mm}$ & $\begin{array}{r}13800 \mathrm{MPa} \\
(1038 \mathrm{MPa})\end{array}$ & $86.8 \mathrm{MPa}$ & $0.71 \%$ \\
& & $830 \mathrm{MPa}$ & $21.2 \mathrm{MPa}$ & $(16.2 \mathrm{MPa})$ \\
\hline cellulose fleece & $0.12 \mathrm{~mm}$ & $(247 \mathrm{MPa})$ & $(0.33 \mathrm{MPa})$ & $6.91 \%$ \\
& & $11800 \mathrm{MPa}$ & $75.7 \mathrm{MPa}$ & $(0.65 \%)$ \\
\hline composite & $0.44 \mathrm{~mm}$ & $(1130 \mathrm{MPa})$ & $(15.6 \mathrm{MPa})$ & $0.66 \%$ \\
& & & & $(0.11 \%)$ \\
\hline
\end{tabular}

std. dev. ..... standard deviation 
Table 2 Results of tensile tests perpendicular to the wood fibre

Tabelle 2 Ergebnisse der Zugprüfungen senkrecht zur Faserrichtung

\begin{tabular}{|l|r|r|r|r|}
\hline \multicolumn{1}{|c|}{ material } & thickness & \multicolumn{1}{c|}{$\begin{array}{c}\text { MOE, } \\
\text { mean value } \\
\text { (std. dev. })\end{array}$} & $\begin{array}{r}\text { tensile strength, } \\
\text { mean value } \\
\text { (std. dev. })\end{array}$ & $\begin{array}{r}\text { tensile strain, } \\
\text { mean value } \\
\text { (std. dev.) }\end{array}$ \\
\hline veneer & $0.41 \mathrm{~mm}$ & $770 \mathrm{MPa}$ & $7.3 \mathrm{MPa}$ & $0.96 \%$ \\
& & $(22 \mathrm{MPa})$ & $(0.7 \mathrm{MPa})$ & $(0.11 \%)$ \\
\hline cellulose fleece & $0.12 \mathrm{~mm}$ & $450 \mathrm{MPa}$ & $12.1 \mathrm{MPa}$ & $14.94 \%$ \\
& & $(50 \mathrm{MPa})$ & $(0.42 \mathrm{MPa})$ & $(2.38 \%)$ \\
\hline composite & $0.47 \mathrm{~mm}$ & $1450 \mathrm{MPa}$ & $7.4 \mathrm{MPa}$ & $0.53 \%$ \\
& & $(300 \mathrm{MPa})$ & $(0.6 \mathrm{MPa})$ & $(0.05 \%)$ \\
\hline
\end{tabular}




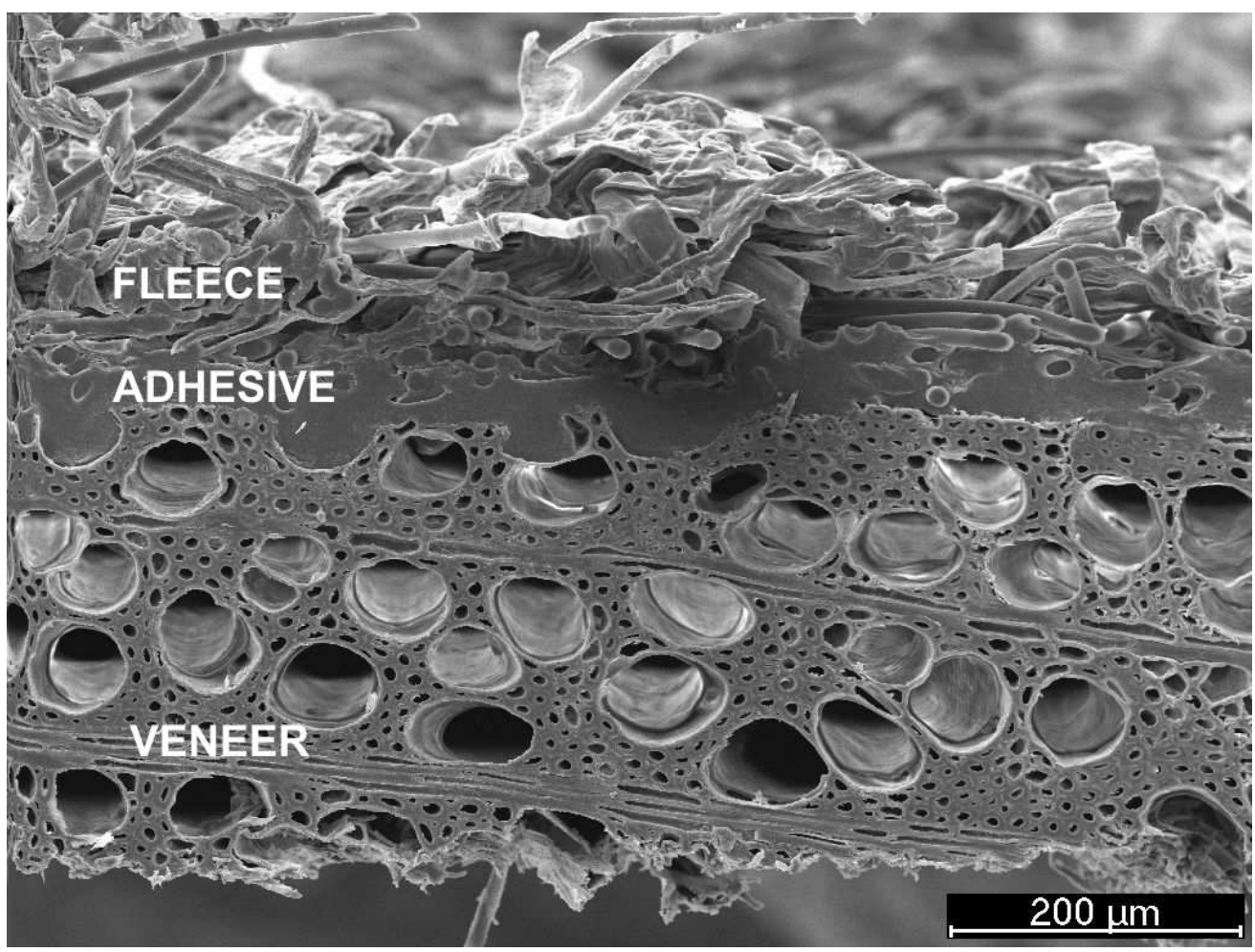

$361 \times 270 \mathrm{~mm}(72 \times 72 \mathrm{DPI})$ 